$\xi=$ 国

\title{
Photochemical Analysis of Food Species of the Cruciferous (Cabbage) Family
}

\author{
Zh. B. Ashirova ${ }^{1 *}$, L. E. Anuarova ${ }^{1}$, N. T. Berik ${ }^{1}$, A. S. Newsome ${ }^{2}$, A. M. Rakhmetova ${ }^{3}$, \\ A. Y. Yessenbekova ${ }^{4}$, Zh. T. Abdrasulova ${ }^{4}$, Zh. Zh. Kuzhantaeva ${ }^{1}$ \\ ${ }^{1}$ Kazakh State Women's Teacher Training University, Aiteke bi Street 99, Almaty, Kazakhstan \\ ${ }^{2}$ Mississippi Valley State University, Department of Biology, Itta Bena, United States \\ ${ }^{3}$ Karaganda State University named after the academician E.A. Buketov, Kazakhstan, Karaganda \\ ${ }^{4}$ Al-Farabi Kazakh national university, al-Farabi Ave., 71, Almaty, Kazakhstan \\ *Corresponding author E-mail: zh.ashirova@bk.ru
}

\begin{abstract}
The article deals with several species of the cruciferous family (Cruciferae Juss.): headed cabbage (Brassica oleracea L.), turnip cabbage (Brassis rapa L.), cultivated radish (Raphanus sativus L.), horseradish (Armoraciarusticana Gaerth.-Mey-Scherb.), Italian asparagus, or broccoli (Brassica Sylvestris L., or Brassica oleracea L.), and others. It has been determined how many micro- and macroelements, as well as fat- or water-soluble vitamins they contain. The phytochemical research has been conducted in the Food Safety and Quality Assessment Laboratory of the Almaty Technological University. The photochemical analysis of the species concerned has been carried out in accordance with GOST 25555.3-82, GOST 30417-69, and M-04-41-2005.
\end{abstract}

Keywords: Flower, seeds, beans, glucoside, photochemical analysis, macroelements, microelements, lentil.

\section{Introduction}

The cruciferous family (Cruciferae Juss.), also called the cabbage family (Brassicaceae), includes annual or perennial herbs, and, in some cases, shrubs. There are 3,200 species belonging to 350 genera spread mainly across the Northern Hemisphere of the world. In Kazakhstan, there are 298 species belonging to 78 families. Most often, species of this family grow in the temperate zone, mainly in mountainous areas, as well as in tropical forests. Their leaves are located alternately or in a rosette. They bloom from March to August. They have sprawling flowers, which can be white, pink, yellow, blue. Flowers can be bisexual with four sepals arranged against one another. One pistil, six stamens, two of which are short and four of which are long. Their fruits are pods or the so-called silicules. Their seeds contain vegetable oils, as well as glucosides. These plants include vegetable, fodder, medicinal, household and honey species.

The vegetable products of the cabbage, or cruciferous family (cabbage, turnip, radish, mustard, horseradish, etc.) are used as dyes (winter cress, woad). Some species are used in the beauty industry, as well as in honey production. Food species are headed cabbage (Brassica oleracea L.), cultivated radish (Raphanus sativus L.), and brown mustard (Brassica juncea L.).

Some fodder species of the cruciferous family growing in the desert regions of Kazakhstan are rare species and are included in the Red List of Kazakhstan. Fifteen plant species of this family are under protection: Arabis popovii Botsch.Vved., Stroganovia robusta Pavl., Stubendorfia gracilis Botsch EtVved., and others. Subject matter of the research: Family: Crucifers (Cruciferae Juss.). Species: headed cabbage (Brassica oleracea L.), turnip cabbage (Brassis rapa L.), cultivated radish (Raphanus sativus L.), horseradish (Armoraciarusticana Gaerth.-Mey-Scherb.), broccoli, or Italian asparagus (Brassica Sylvestris L., or Brassica oleracea L.).

Purpose of the research: To determine the content of water- and fat-soluble vitamins, as well as macro- and microelements in the plants of the cruciferous family (Cruciferae Juss.) grown on vegetable farms of the Almaty Region.

\section{Materials and Methods}

The phytochemical research has been conducted in the Food Safety and Quality Assessment Laboratory of the Almaty Technological University. The photochemical analysis of the species concerned has been carried out in accordance with GOST 25555.3-82, GOST 30417-69 and M-04-41-2005.

\section{Discussion}

Headed cabbage (Brassica oleracea L.). It is a biennial cultivated plant of the cruciferous family (Figure 1). It has a stout and well-branched root system. The headed cabbage comes from the Mediterranean coast, Ancient Greece. In Russia, the headed cabbage appeared much later. Ancient manuscripts referring to the cabbage date back to 1073 . Consuming $200 \mathrm{~g}$ of cabbage every day prevents cold and improves digestion, as well as protects people against vitamin $\mathrm{C}$ deficiency. The cabbage also contains the antiulcer vitamin $U$ which helps treat this rare digestive disease. Ä. Eskendirov determined the composition of the cabbage (1982); Ä. Nisanbaev found that the cabbage contained vitamin U $(1998)[1,2]$. The phytochemical analysis determined the amount of vitamins, as well as the quality and quantity of mineral 
elements. Cruciferous species contain some mineral elements such as sulfur, phosphorus, calcium, potassium, and chlorine.

According to the research findings, the content of $\mathrm{Ca}$ was $7.12 \mathrm{mg}$ per $100 \mathrm{~g}, \mathrm{Mg}-31.57 \mathrm{mg}$ per $100 \mathrm{~g}$, and $\mathrm{Fe}-16.9 \mathrm{mg}$ per $100 \mathrm{~g}$. The vitamin content was as follows: vitamin $\mathrm{E}-0.06 \mathrm{mg}$ per 100 $\mathrm{g}$, vitamin $\mathrm{C}-0.038 \mathrm{mg}$ per $100 \mathrm{~g}, \mathrm{~B}_{2}$ (riboflavin) $-0.016 \mathrm{mg}$ per $100 \mathrm{~g}, \mathrm{~B}_{6}$ (pyridoxine) $-0.0096 \mathrm{mg}$ per $100 \mathrm{~g}, \mathrm{~B}_{3}$ (pantothenic acid) $-0.0053 \mathrm{mg}$ per $100 \mathrm{~g}$, and $\mathrm{B}_{5}$ (nicotinic acid) $-0.0021 \mathrm{mg}$ per $100 \mathrm{~g}$.

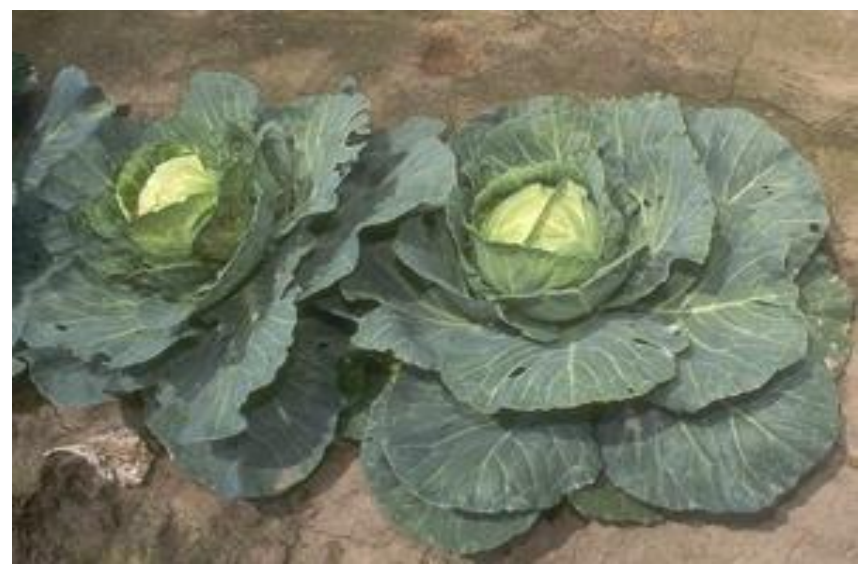

Fig. 1: Headed cabbage (Brassica oleracea L.).

The turnip cabbage (Brassis rapa L.) is a biennial herbaceous plant of the cabbage family (Figure 2). It is edible, and its root vegetable is white or yellow. In its first year, the plant gains its leaves and a thick root vegetable, and in its second year, it blooms and bears its fruit. It has sprawling flowers, which are red and yellow or yellowish. Its fruits are pods. The turnip cabbage is pollinated by insects, and it is resistant to cold and prefers moist environment. It grows well at a temperature of 12 to $20^{\circ} \mathrm{C}$. Vegetation period is 60 to 85 days. The turnip grows well in clay and sandy soil. Its seeds are planted in spring [3]. According to the research findings, the content of $\mathrm{Ca}$ in turnip cabbage fruit was $8.67 \mathrm{mg}$ per $100 \mathrm{~g}, \mathrm{Mg}-21.3 \mathrm{mg}$ per $100 \mathrm{~g}$, and $\mathrm{Fe}-5.8 \mathrm{mg}$ per $100 \mathrm{~g}$. The vitamin content was as follows: no vitamin $\mathrm{E}$ was found; vitamin C $-0.044 \mathrm{mg}$ per $100 \mathrm{~g}$; $\mathrm{B}_{2}$ (riboflavin) $-0.012 \mathrm{mg}$ per $100 \mathrm{~g}$; $\mathrm{B}_{6}$ (pyridoxine) - $0.0049 \mathrm{mg}$ per $100 \mathrm{~g}$; no $\mathrm{B}_{3}$ was found; and no $\mathrm{B}_{5}$ was found.

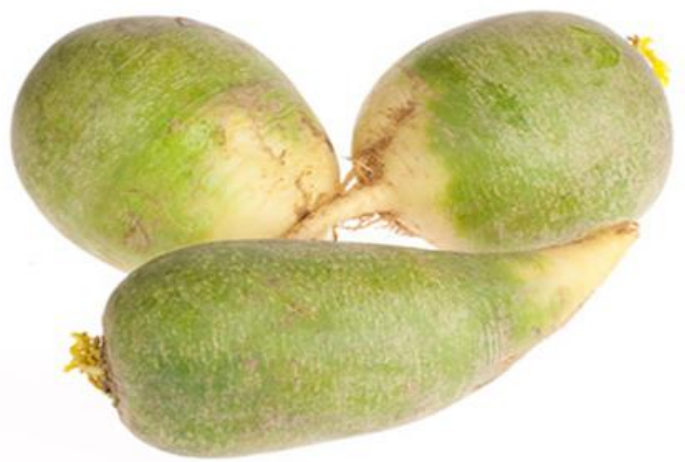

Fig. 2: Turnip cabbage (Brassis rapa L.).

Cultivated radish (Raphanus sativus L.). It is a biennial plant resistant to cold, member of the cabbage family (Figure 3). In its first year, the plant gains its leaves and a thick root vegetable, and in its second year, it blooms and bears its fruit. It has sprawling flowers, and it is cross-fertilized. Its fruit are pods. It can be easily hybridized with the annual cultivated radish, as well as the wild radish (garden radish) (Raphanus sativus L. Var. Radicula). It is grown in all the CIS regions. Its root, which is its fruit, is used as food and sometimes in pharmaceutical manufacturing. The cultivated radish (the black radish) has some antibacterial properties and helps restore the production of gastric juice $[4,5]$. Some varieties of the cultivated radish ripen late (in autumn), and some ripen early. The best varieties of the radish are as follows: Grayvoronskaya radish (with an oval white root vegetable), winter black radish (with a round root vegetable, black outside and white inside), winter white radish (with a white root vegetable and a bitter taste), local Dungan radish (with a round or elongated root vegetable and a bitter taste), etc. [6]. According to the research findings, the content of $\mathrm{Ca}$ in radish fruit was $7.82 \mathrm{mg}$ per $100 \mathrm{~g}$, $\mathrm{Mg}-26.31 \mathrm{mg}$ per $100 \mathrm{~g}$, and $\mathrm{Fe}-20.1 \mathrm{mg}$ per $100 \mathrm{~g}$ (Table 1). The vitamin content was as follows: no vitamin $\mathrm{E}$ was found; vitamin $\mathrm{C}-0.089 \mathrm{mg}$ per $100 \mathrm{~g}$; $\mathrm{B}_{2}$ (riboflavin) - $0.013 \mathrm{mg}$ per $100 \mathrm{~g}$; $\mathrm{B}_{6}$ (pyridoxine) $-0.0038 \mathrm{mg}$ per $100 \mathrm{~g}$; vitamin $\mathrm{B}_{3}-$ 0.0049 ; and vitamin $\mathrm{B}_{5}-0.00041$ (Table 2).

Table 1: Micro- and macroelements contained in plants of the studied species

\begin{tabular}{llllll}
\hline $\begin{array}{l}\text { Mineral } \\
\text { elements } \\
\text { mg per 100 g }\end{array}$ & $\begin{array}{l}\text { Headed cabbage } \\
\text { (Brassica } \\
\text { oleracea L.) }\end{array}$ & $\begin{array}{l}\text { Turnip cabbage } \\
\text { (Brassis rapa L.) }\end{array}$ & $\begin{array}{l}\text { Cultivated radis } \\
\text { h (Raphanus } \\
\text { sativus L.). }\end{array}$ & $\begin{array}{l}\text { Horseradish } \\
\text { (Armoracia } \text { Gaerth.- } \\
\text { Mey-Scherb.) }\end{array}$ & $\begin{array}{l}\text { Broccoli, or Italian } \\
\text { asparagus (Brassicaoleracea, Test method } \\
\text { or Brassica sylvestris) }\end{array}$ \\
\hline 1 & 2 & 3 & 4 & 5 & 6 \\
$\mathrm{Ca}$ & 7.12 & 8.67 & 7.82 & 11.17 & 9.83 \\
$\mathrm{Mg}$ & 31.57 & 21.3 & 26.31 & 87.4 & 33.24 \\
$\mathrm{Fe}$ & 16.9 & 5.8 & 20.1 & 25.01 & GOST 25555.3-82 \\
\hline
\end{tabular}

Table 2: Vitamin composition of the studied species

\begin{tabular}{|c|c|c|c|c|c|c|}
\hline $\begin{array}{l}\text { Vitamins, } \\
\text { mg per } 100 \mathrm{~g}\end{array}$ & $\begin{array}{l}\text { Headed cabbage } \\
\text { (Brassica } \\
\text { oleracea L.) }\end{array}$ & $\begin{array}{l}\mathbf{e}_{\text {Turnip cabbage }} \\
\text { (Brassis rapa } \mathbf{L} .)\end{array}$ & $\begin{array}{l}\text { Cultivated radish } \\
\text { (Raphanus sativus L.). }\end{array}$ & $\begin{array}{l}\text { Horseradish } \\
\text { (Armoracia Gaerth.- } \\
\text { Mey-Scherb.) }\end{array}$ & $\begin{array}{l}\text { Broccoli, or Italian } \\
\text { asparagus (Brassicaoleracea, } \\
\text { or Brassica sylvestris) }\end{array}$ & Test method \\
\hline 1 & 2 & 3 & 4 & 5 & 6 & 7 \\
\hline $\mathrm{E}$ & 0.06 & Not found & Not found & Not found & 0.94 & GOST 30414-96 \\
\hline $\mathrm{C}$ & 0.038 & 0.044 & 0.0089 & Not found & 0.017 & M-04-41-2005 \\
\hline $\mathrm{B}_{2 \text { riboflavin }}$ & 0.016 & 0.012 & 0.013 & 0.013 & 0.013 & M-04-41-2005 \\
\hline $\mathrm{B}_{6 \text { pyridoxine }}$ & 0.0096 & 0.0049 & 0.0038 & 0.0044 & 0.005 & M-04-41-2005 \\
\hline $\mathrm{B}_{3 \text { pantothenic acid }}$ & 0.0053 & Not found & 0.0049 & 0.0029 & Not found & M-04-41-2005 \\
\hline $\mathrm{B}_{5 \text { nicotine acid }}$ & 0.0021 & Not found & 0.00041 & 0.00025 & 0.00041 & M-04-41-2005 \\
\hline $\mathrm{B}_{9 \text { folic acid }}$ & Not found & Not found & Not found & Not found & 0.00055 & M-04-41-2005 \\
\hline
\end{tabular}

White mustard (Sinapis alba L.). It belongs to the cruciferous family (Figure 4). Some seeds are used in pharmaceutical manufacturing. The plant blooms in June and July, and it is an annual herbaceous weed growing in the fields of southern and central former USSR countries. Its green seeds are sown as animal feed and raw material for flour and oil production. Mustard seeds contain up to 35 to $47 \%$ fat [7].
Horseradish (Armoraciarusticana Gaerth.-Mey-Scherb.). It is a perennial plant of the cruciferous family (Figure 5). It is sown in all regions of Kazakhstan. One of its species - the horseradish grows in fields and vegetable gardens as a wild plant. It is grown in many regions of Kazakhstan. The height of the horseradish is about one meter. Its trunk is straight, and its top is branched. It has a white fragrant flower. It blooms in June and it is propagated 
vegetatively [8]. It is resistant to cold. Its root and leaves contain potassium, sodium, phosphorus, iron, chlorine, copper, essential oils, vitamin C, phytoncides, lysozymes, etc. The roots and green leaves of the plant are used in preservation and salting of cucumbers, tomatoes, and mushrooms. The horseradish is used to treat lumbar radiculitis, diseases affecting muscles, back and lumbar region, as well as rheumatism and joint diseases. Its leaves are used as a bandage applied to various wounds [9]. According to the research findings, the content of $\mathrm{Ca}$ in the plant is $11.17 \mathrm{mg}$ per $100 \mathrm{~g}, \mathrm{Mg}-87.4 \mathrm{mg}$ per $100 \mathrm{~g}$, and $\mathrm{Fe}-25.01 \mathrm{mg}$ per $100 \mathrm{~g}$. Vitamin content is the following: no vitamin $\mathrm{E}$ was found; no vitamin $\mathrm{C}$ was found; $\mathrm{B}_{2}$ (riboflavin) $-0.013 \mathrm{mg}$ per $100 \mathrm{~g}$; $\mathrm{B}_{6}$ (pyridoxine) - $0.0044 \mathrm{mg}$ per $100 \mathrm{~g}$; vitamin $\mathrm{B}_{3}-0.0029$; and vitamin $\mathrm{B}_{5}-0.00025 \mathrm{mg}$ per $100 \mathrm{~g}$.

Broccoli, or Italian asparagus (Brassica oleracea, or Brassica sylvestris). It is an annual species of the cabbage family (Figure 6). In its first year, its stem reaches 60 to $90 \mathrm{~cm}$ in height and forms multiple succulent branches (peduncles) on the top ending with dense groups of small green buds. The best environment for the broccoli is cool damp climate with a temperature of 18 to $23^{\circ} \mathrm{C}$. When its buds become bright yellow, it means that the broccoli is overripe and not suitable for consumption [10, 11]. The plant is rich in microelements, especially vitamins $\mathrm{C}$ and $\mathrm{K}$. In its vitamin A content, it prevails over all other types of cabbage. According to the research findings, the content of $\mathrm{Ca}$ is $9.83 \mathrm{mg}$ per $100 \mathrm{~g}, \mathrm{Mg}-33.24 \mathrm{mg}$ per $100 \mathrm{~g}$, and $\mathrm{Fe}-17.8 \mathrm{mg}$ per $100 \mathrm{~g}$. Vitamin content is the following: vitamin $\mathrm{E}-0.94 \mathrm{mg}$ per $100 \mathrm{~g}$; vitamin $\mathrm{C}-0.017 \mathrm{mg}$ per $100 \mathrm{~g}$; $\mathrm{B}_{2}-0.013 \mathrm{mg}$ per $100 \mathrm{~g}$; $\mathrm{B}_{6}-$ $0.005 \mathrm{mg}$ per $100 \mathrm{~g}$; no $\mathrm{B}_{3}$ was found; $\mathrm{B}_{5}$ (nicotinic acid) $0.00041 \mathrm{mg}$ per $100 \mathrm{~g}$; and $\mathrm{B}_{9}$ (folic acid) $-0.00055 \mathrm{mg}$ per $100 \mathrm{~g}$. The broccoli restores the magnesium content in the body. Insufficient magnesium content causes irregular heartbeat (arrhythmia), nervous and intestinal disorders, depression, and even bone and tooth diseases.

The most unpretentious and long-growing type of cabbage is the Brussels sprouts (Brassica oleracea var. gemmifera) (Figure 7). The Brussels sprouts grows even in barren soil. As it needs quite a long time to develop shoots forming the original Brussels sprouts product (about 150 days), it is not planted without seedlings. The best time for planting its seeds is believed to be early April. Its seedlings are grown on a closed balcony - loggia - or in greenhouses. The most favorable temperature for seedlings is 16 to $18^{\circ} \mathrm{C}$ in the daytime and 5 to $6^{\circ} \mathrm{C}$ at night. Beta-carotene contained in this type of cabbage forms the immune system, facilitates cell growth and water removal from the body, clears it from toxins, and helps reduce excess weight [12].

Kohlrabi (Brassica oleracea var. gongyloides). Kohlrabi tubers are stalks (Figure 8). Its fruits are juicy and a bit sweet. The kohlrabi comes from Northern Europe. The German word "kohlrabi" means "cabbage radish (turnip)". The kohlrabi contains a large amount of vitamin $\mathrm{C}$, as well as vitamins $\mathrm{A}, \mathrm{B}, \mathrm{PP}$, and $\mathrm{B}_{2}$. This plant is rich in vegetable proteins, carbohydrates, mineral salts, calcium, potassium, phosphorus, magnesium, carotene, pantothenic acid (vitamin $\mathrm{B}_{5}$ ), cobalt, and iron. Fructose and glucose contained in its juicy and tender white fruit are easily digested in the body making people feel full. The digestibility of vitamins contained in the kohlrabi is higher than that of vitamins contained in apples. It helps prevent all kinds of infectious diseases. The kohlrabi not only helps reduce weight, but also normalizes metabolism, so it is extremely useful for those who want to keep fit for a long time. The kohlrabi provides the body with energy, oxygen, helps regulate metabolism, takes part in haematopoiesis, improves the functioning of the heart, and reduces weight [13-15].

Leaf cabbage (Brassica oleracia acephala L.). The leaf cabbage is a cultivated plant with large curly leaves which are eaten all over the world. This type of cabbage can be found in almost every public catering establishment (Figure 9). The leaf cabbage can be eaten raw and added to salads. It can also be boiled and heat- treated in other ways (fried, baked, or steamed). It is grown in autumn and winter. The leaf cabbage reduces the cholesterol and fat content in blood, slows down aging, and provides the body with essential fiber and protein, carbohydrates, as well as all microelements and vitamins.

The juice obtained from its leaves is used to treat chronic low acidity gastritis, wounds of the duodenum, liver, and spleen, as well as to reduce excess weight.

Cauliflower (Brassica oleracea L.). This plant is a very valuable food product. It does not take long to ripen, and its composition in terms of vitamin content and nutritional value is similar to that of the Brussels sprouts.

Boiled cauliflower heads (modified inflorescences) are used as food being rich in protein and carbon. This type of cabbage contains more vitamins and minerals than the white cabbage.

For this reason, the cauliflower should be used in children's and sick people's diets. It is normally used in soups, boiled or fried. Sometimes the cauliflower is preserved.

In the ancient times, the cauliflower juice was used to treat lung diseases. Modern medicinal plant specialists recommend drinking one teaspoon of this juice several times a day to treat cough or hoarse voice [14]. The cauliflower is a beautiful and useful vegetable which accelerates the growth and renewal of body cells, reduces weight, strengthens the immune system, reduces blood pressure, and prevents colon diseases (Figure 10).

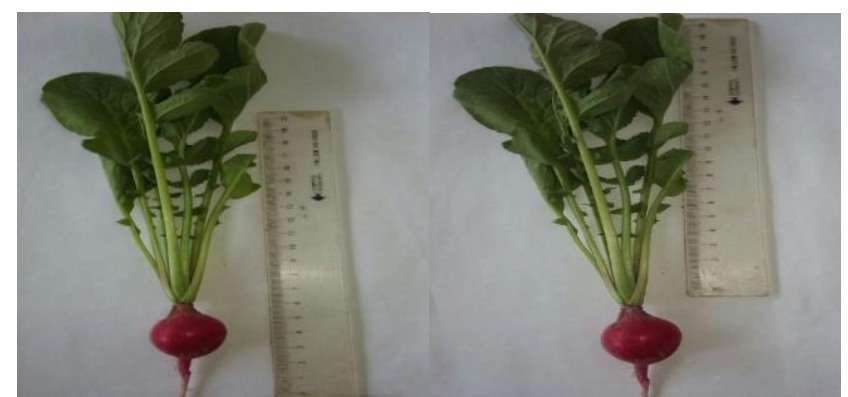

Fig. 3: Cultivated radish (Raphanus sativus L.)

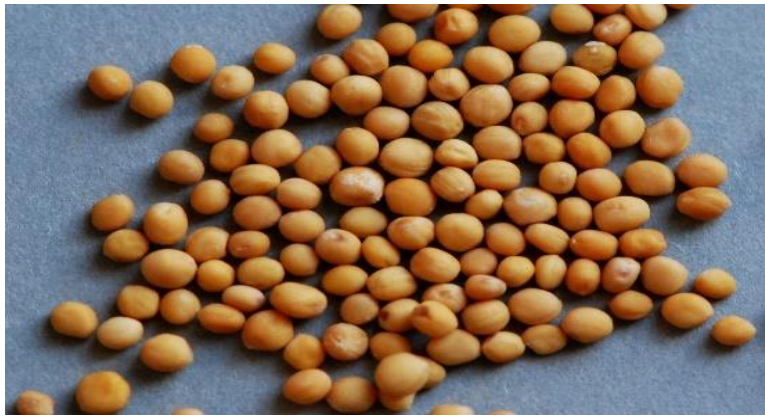

Fig. 4: White mustard seeds (Sinapis alba L.).

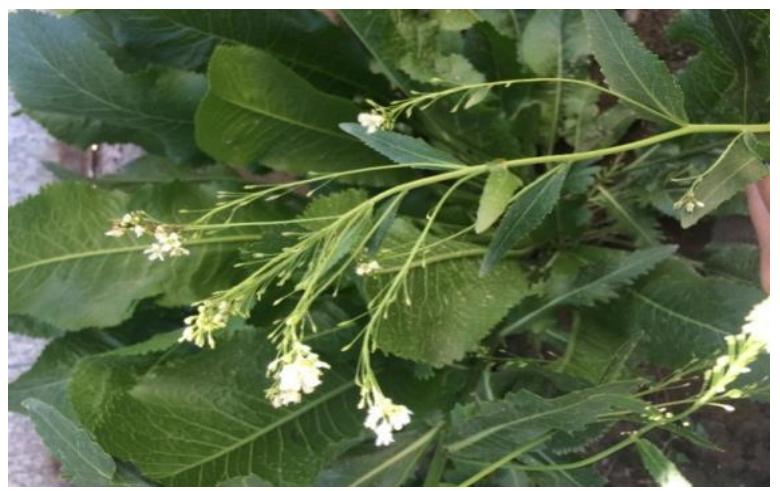

Fig. 5: Horseradish (Armoraciarusticana Gaerth.-Mey-Scherb.). 


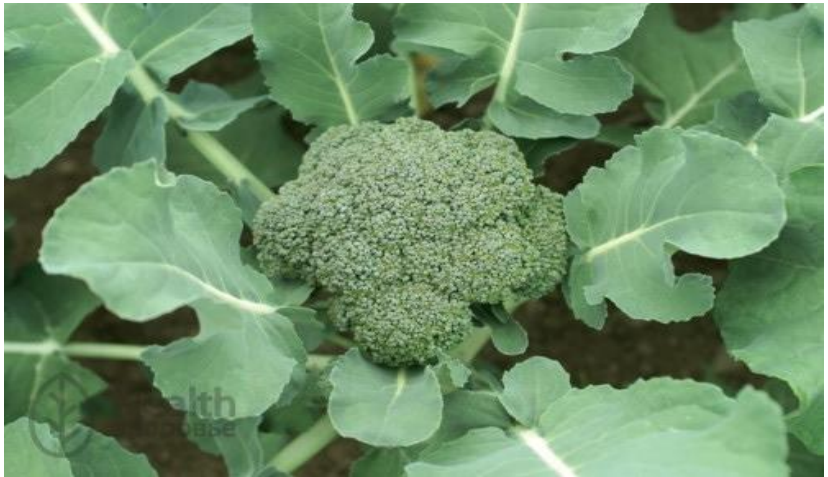

Fig. 6: Broccoli / Italian asparagus (Brassica oleracea L.).

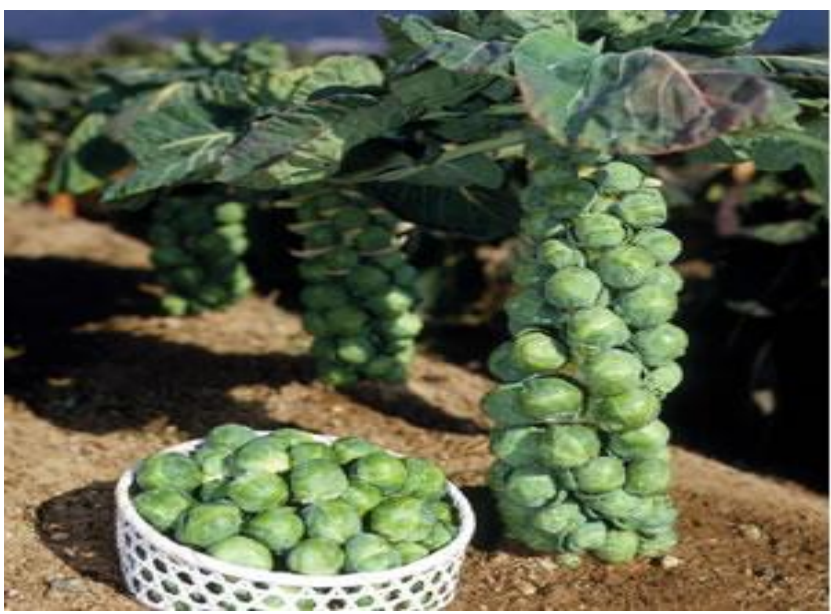

Fig. 7: Brussels sprouts (Brassica oleracea var. gemmifera).

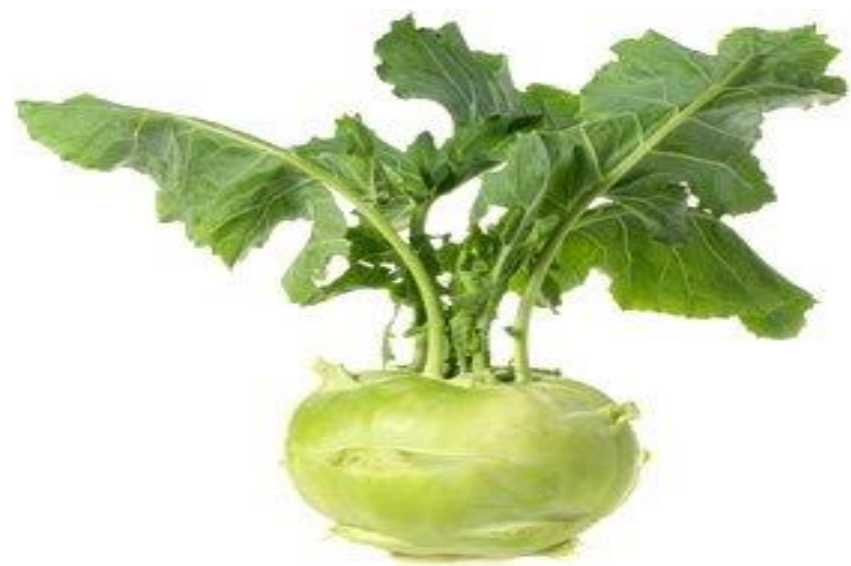

Fig. 8: Kohlrabi (Brassica oleracea var. gongylodes).

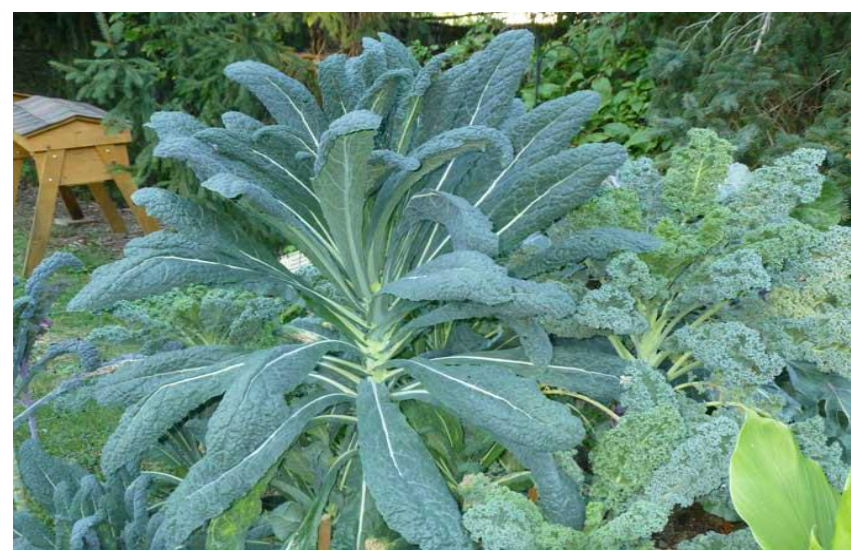

Fig. 9: Leaf cabbage (Brassica oleracia acephala L.).

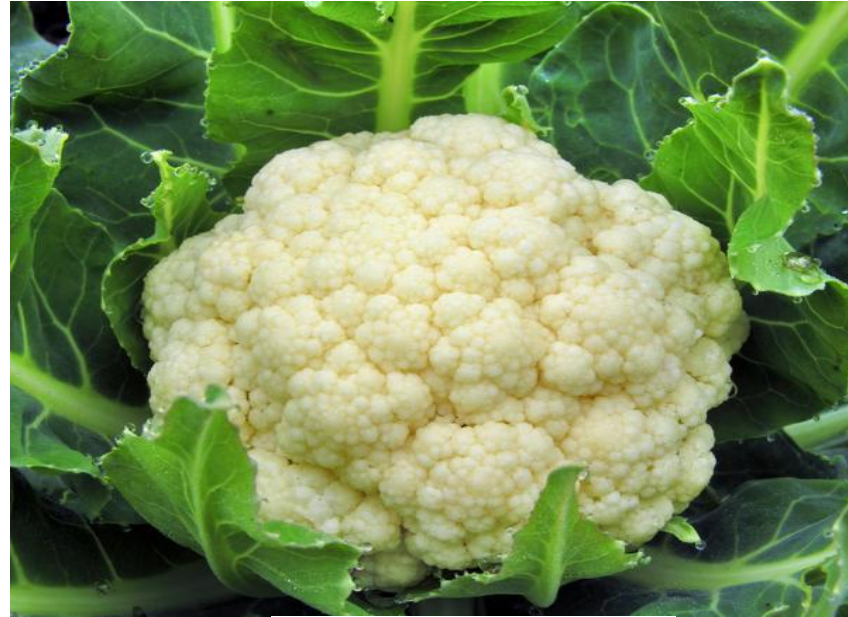

Fig. 10: Cauliflower (Brassica oleracea L.).

\section{Conclusion}

As the research shows, the content of $\mathrm{Ca}$ in the horseradish (Armoracia Gaerth.-Mey-Scherb.) amounts to $11.17 \mathrm{mg}$ per $100 \mathrm{~g}$, which is much higher than the content of this microelement in the other types of cruciferous plants described in the article. The lowest content of $\mathrm{Ca}(7.12 \mathrm{mg}$ per $100 \mathrm{~g})$ has been found in the headed cabbage (Brassica oleracea L.). The horseradish (Armoracia Gaerth.-Mey-Scherb.) also has the highest content of $\mathrm{Mg}$ (87.4 mg per $100 \mathrm{~g}$ ), and as for the turnip cabbage (Brassis rapa L.), it has the lowest content of this microelement compared to the other species -21.3 per $100 \mathrm{~g}$. The highest Fe content (25.01 $\mathrm{mg}$ per $100 \mathrm{~g}$ ) has also been found in the horseradish samples (Armoracia Gaerth.-Mey-Scherb.), and the turnip cabbage (Brassis rapa L.) has again showed the lowest Fe content $(5.8 \mathrm{mg}$ per $100 \mathrm{~g})$. No vitamin $\mathrm{E}$ has been found in some of the species, such as the turnip cabbage (Brassis rapa L.), cultivated radish (Raphanus sativus L.), and horseradish (Armoracia Gaerth.-Mey-Scherb.). Vitamin C has been found in the cultivated radish (Raphanus sativus L.) in the amount of $0.0089 \mathrm{mg}$ per $100 \mathrm{~g}$, and none has been found in the horseradish. The same amount of vitamin $\mathrm{B}_{2}-0.013 \mathrm{mg}$ per $100 \mathrm{~g}$ - has been found in the cultivated radish (Raphanus sativus L.), horseradish (Armoracia Gaerth.-Mey-Scherb.), and broccoli, or Italian asparagus (Brassica oleracea, orBrassica sylvestris). A high amount of vitamin $\mathrm{B}_{6}-0.0096 \mathrm{mg}$ per $100 \mathrm{~g}-$ is contained in the headed cabbage (Brassica oleracea L.), while the broccoli (Brassica oleracea) does not contain much of it - just $0.005 \mathrm{mg}$ per $100 \mathrm{~g}$. No vitamin $\mathrm{B}_{3}$ has been found in the headed cabbage (Brassis rapa L.), broccoli, or Italian asparagus (Brassica oleracea, or Brassica sylvestris). No nicotinic acid (vitamin $\mathrm{B}_{5}$ ) has been found in the turnip cabbage (Brassis rapa L.). Folic acid $\left(\mathrm{B}_{9}\right)$ is contained in the broccoli, or Italian asparagus (Brassica oleracea, or Brassica sylvestris) in the amount of $0.00055 \mathrm{mg}$ per $100 \mathrm{~g}$, and it has not been found in the other four types of cruciferous species considered in the article.

\section{Ethical clearance}

Not required as the he study was conducted on the plants.

\section{Source of funding}

Self.

\section{Conflict of interest}

Nil. 


\section{References}

[1] Eskendirov, A. Qazaqstannı̃ därilik ösimdikteri [Medicinal Herbs in Kazakhstan], Almaty Kazakhstani Bookish Publishing House , 1982; pp. 63-64.

[2] Nısanbaev, Ä. Ulttıq éncïklopedïya [National Encyclopedia]. Almaty, Kazakh Encyclopedia. General Edition,1998.

[3] Quljabaeva, Q. Ösimdikter älemi, G.Ä. Oqw-ädistemelik keşeni, kökönister: Dïdaktïkalıq materïal [Plants World. Educational and Methodical Complex, Vegetables: Didactical Material]. Almaty, 2011, pp. 16

[4] Aitbaev, T.E., Amirov, B.M., Dzhanabayeva, T.T. Potato and Hybrid Potatoes and Wheat Cultures Selection of the Kazakh Research Institute of Potato Farming and Breeding, Finding Used Farms in Kazakhstan and Perspective. Almaty, 2014, 94 p.

[5] Raven, P., Evert, R., Eichhorn, S. Sovremennaya Botanika [Biology of Plants]. Translation from English edited by A.L. Takhtadzhian. Moscow, MIR, 1990, 129 p.

[6] Flora Kazakhskoi SSR [Flora of the Kazakh SSR]. In four vol Almaty, 1961, $215 \mathrm{p}$

[7] Mwxïtdïnov, N.M., Mamwrova, A.T. Därilik ösimdikter [Herbaceous Plants], Almaty, 2013, 45 p.

[8] Ionova, A.A., Mitso, V.P. Bolshaya entsiklopediya narodnoi meditsiny [The Big Encyclopedia of Folk Medicine]. Moscow, Olma Media Group, 2009, pp. 497-498.

[9] Arıstanğaliev, S.A., Ramazanov, E.R. Qazaqstan ösimdikteri [Plants of Kazakhstan]. Almaty, 1977, 98 p

[10] Zhukovskii, P.M. Botanika [Botany]. Moscow, 1964.

[11] Zhizn rastenii [Plant Life], 5.

[12] Raven, P., Evert, R., Eichhorn, S. Sovremennaya Botanika [Biology of Plants]. Moscow, Mir Publishing House, 1990.

[13] Lavrenova, G.V., Lavrenov, V.K. Polnaya entsiklopediia lekarstvennykh rastenii [The Full Encyclopedia of Medicinal Plants]. Stalker Publishing House [Harvest, LLC], 2008.

[14] Abdrassulova, Zh.T., Rakhmetova, A.M., Tusupbekova, G.A., Imanova, E.M., Agadieva M.S., Bissalyyeva, R.N. Identification of fungi storage types by sequencing method. Journal of Pharmaceutical Sciences and Research 10(2), (2018), 689-692.

[15] Abdrassulova, Zh.T., Ashirova, Z.B., Issayev, G.I., Tuleukhanov, S.T., Ursheeva, B.I., Omirbek, N.A. The effectiveness of knowledge acquisition for students using innovative methods of teaching biology. Journal of Pharmaceutical Sciences and Research 10(2), (2018), 416-419. 